\title{
Analysis of Industrial Organizational Structure of West China
}

\author{
Xinshu Gong \\ School of Economic \& Trade, Shihezi University, Shihezi 832000, China \\ Tel: 86-993-239 7002 E-mail: gxsh-xb@163.com \\ Xuefeng Wang \\ School of Economic \& Trade, Shihezi University, Shihezi 832000, China
}

Tel: 86-993-231 $1548 \quad$ E-mail: rodin2050@yahoo.com.cn

\begin{abstract}
Comparing with developed areas of Mid-eastern China, the present industrial organizational structure of West China can far from adopt the objective requirements of economical development. In this article, we detailedly analyze the main problems existing in the industrial organizational structure of West China which include low level of scale economy, high proportional state-owned economy, low level of specialization division and collaboration, excessive large and complete, small and complete omnipotent corporations, and put forward the optimized methods of industrial organizational structure of West China.
\end{abstract}

Keywords: Industrial organizational structure, Optimized method, West China

Industrial organizational structure in modern industrial economics means the structure and relations among enterprises in same industry (or market), which not only includes enterprise scale and scale structure, i.e. respective proportions of large-sized, middle-sized and small-sized enterprises and market competitive relations, but also includes relations of mutual labor division and collaboration among enterprises that produce same variety products. Reasonable industrial organizational structure should not only keep competitive energy under the market mechanism and make enterprises in the industry have enough impetus and pressures to improve management and technology and reduce costs, but also fully utilize scale economy and avoid low efficiency brought by excessive competitions.

\section{Main problems existing in present institutional organizational structure of West China}

With the development of China market economy and deepening of industrialization, industrial organization conformation of West China has be quite improved, but comparing with developed areas of mid-eastern China, the present industrial organizational structure of West China has not adopted the objective requirements of economical development, and many problems still need to be solved. These problems mainly are the following aspects.

\subsection{Low degree of industrial concentration}

Industrial concentration degree is one important factor of market structure, which is the common index to measure industrial competition and monopolization and can be represented by shares of some relative numerical values (such as production value, output, sale, employee number, assets amount and so on) which occupy the whole market or industry for several enterprises which scales are the most in a certain industry. The irrationality of market structure of industrial organization of West China is mainly embodied in the industrial departments which should have high concentration degree, but the production proportions of several large-sized enterprises in West China are very low and even can not achieve the normal scale which the technology requires. According to the relative data of "China Industrial Economic Statistical Yearbook in 2004", we primarily calculate the concentration index $\left(\mathrm{CR}_{4}\right)$ of market share of sales of the four biggest enterprises in eight industries in West China, and the results are seen in Table 1.

\subsubsection{Industry of transport equipment manufacturing}

The industry of transport equipment manufacturing is the industry with remarkable benefits of scale economy, and the production scales of the enterprise is larger, the production efficiency is higher. So the specialized production must be organized by the principle of scale economy, and which is the interior requirements to develop transport equipment manufacturing industry. But to our worry, at present, the concentration of foreign auto production is continually enhanced, and the ten biggest auto corporations in the world have $80 \%$ of the world output, but the proportion of auto output of three factories which have the most outputs in China auto industry can not achieve 50\% in total output of China, and the auto production in West China is more extremely dispersed, which can be proved by the data that the market concentration degree $\left(\mathrm{CR}_{4}\right)$ of transport equipment manufacturing is only $16.6 \%$.

\subsubsection{Industry of production and supply of electric power and heat}

Industry of production and supply of electric power and heat is one of industries which have weak competition and remarkable scale benefits. The production concentration degree of this industry is very low and the decentralization 
and repetition in this industry are serious in West China. For a long time, there has not formed a passel of large-sized enterprises or enterprise groups which occupy biggish market share and can represent industrial level. In 2003, the market concentration degree $\left(\mathrm{CR}_{4}\right)$ of this industry in West China was $39.4 \%$ which was lower than the national level.

\subsubsection{Industry of tobacco processing}

There are abundant tobacco resources in West China, but there lack tobacco enterprises with large scales. Even some provinces have no enterprises with scales or over scales. In 2003 , the concentration degree $\left(\mathrm{CR}_{4}\right)$ of tobacco processing industry was $41.7 \%$ in West China.

\subsubsection{Industry of petroleum and natural gas extraction}

Though China resources of petroleum and natural gas are centralized in West China, but in 2003, the concentration degree $\left(\mathrm{CR}_{4}\right)$ of petroleum and natural gas extraction industry was only $14.5 \%$.

\subsection{Low level of scale economy}

Another predominant problem existing in the western industrial organization is the low level of scale economy, unreasonable scale structure of enterprise and the miniaturization tendency of enterprise scale. The enterprise scale structure is the proportional relations of composing and quantity for enterprises with different scales (such as the sorts of large-sized, middle-sized and small sized enterprises). The enterprise scale structure reflects the situations of scale economy utilization and technical advancement to large extent, which has important influences to market structure conformation and market operation efficiency. Usually, if the small-sized enterprises with low degree of specialized collaboration have large proportion, the benefits of scale economy are low.

According to the statistic of "China Industrial Economic Statistical Yearbook in 2004", in 2003, the amount of enterprises in West China which entered 500 largest industrial enterprises were only 74 occupying $14.8 \%$, and the amount of enterprises in West China which entered 1000 largest industrial enterprises were 135 occupying $13.5 \%$, and they are lower than the proportion of domestic total production value of western 12 provinces occupying national gross in 2003, which indicated the quantity of large-sized industrial enterprises in West China are less, and as viewed from industries, the western enterprises entering China 500 or 1000 largest industrial enterprises are monopolized industries strictly controlled by the country such as petroleum extraction, electric power, petrifaction, tobacco, steel and other industries, but few industries with strong competition and high technical content belongs to West China. In addition, in 2003, the number of western state owned and non-state industrial enterprises above scale was 24111, where the number of large-sized enterprise was 353 occupying $1.464 \%$ of the whole number, the number of middle-sized enterprise was 3092 occupying 12.824\%, and the number of small-sized enterprise was 20666 occupying $85.712 \%$. It is obvious that in the industrial enterprises of West China, the large-sized and middle-sized enterprises occupy fewer shares, the small-sized enterprises occupy more shares, and the western industrial enterprises generally have the tendency of miniaturization.

\subsection{High proportional state-owned economy}

From Table 2, we can see that in the western industrial enterprises, the industrial gross proportion, industrial increase value proportion, assets amount proportion and other indexes of state-owned and state holding enterprises are obviously higher than the whole country and East.

The direct influences of high proportional state-owned economy to the industrial organization are to induce low industrial market performances. Some scholars carried through the statistic analysis to the 170 thousand enterprises in national 20 industrial, and found out that the efficiencies of the privately-run enterprise and the individual enterprise are the highest, and then the three kinds of foreign-invested enterprises, and then the corporate enterprises and the collective enterprises, and the state-owned enterprises possess the lowest efficiencies. The low efficiencies of enterprises induce the low market performances of the whole industry, accordingly which make western economy lack energy and power to develop.

\subsection{Low level of specialization division and collaboration among enterprises and excessive large and complete,} small and complete omnipotent corporations

After 50 years' developments, though the West China has formed independent and comparatively complete industrial system, but as viewed from the organizational forms and associated methods among enterprises, because they were tied by the planned economy, most enterprises are still staying in the developing stage with self-forming system, and the specialized levels of the enterprises are still very low and the collaborate relation among enterprises is relatively incompact. Especially, the enterprises with industrial association and intense relations in products can not emphasize collaboration and exert their own advantages, but conversely develop each other. In the machine-building industrial enterprises in West China, $80 \%$ of them belong to "omnipotent enterprises", enterprises 
with self-forging and casting are above $80 \%$ and $90 \%$ of the whole machine-building industry, but comparing with foreign same variety enterprise, the enterprises with self-forging in US occupy less $40 \%$, and this proportion in Japan is only about $15 \%$. Low specialized level must produce low collaborate level of enterprise, less association of production and technology, which limits the enhancement of the scale economy level and reduces the labor productivity and economical benefits.

Most western small-sized enterprises have the character of "small but complete", but haven't the advantage of specialized collaboration. In western countries with developed market economy, when the large-sized enterprises are developing, the small-sized enterprises are also fully growing up. For example, in Japan, small-sized enterprises with tens of employee occupy $51.3 \%$ of the sum of Japanese enterprises, and these small-sized enterprises are established on the base of specialized labor division and collaboration, form organic associations with the whole industrial organizational structure, when the large-sized enterprises enjoy scale economy, they will enjoy the benefits of socialization production and labor division and collaboration. Large-sized enterprises in developed countries usually have thousands of collaborate enterprises to corporate with them, but in China, the specialized collaboration can not deserve emphasis, and most industrial enterprises are "omnipotent enterprises", and which induces the results of undeveloped production technics, small batch production, high costs and low efficiencies.

\section{Optimized methods of industrial organizational structure of West China}

From above analysis, we can see that the present western industrial organization still has biggish differences in the aspects of industrial concentration degree, specialized division and collaboration comparing with mid-eastern developed areas, which has seriously limited the further developments of western economy. To promote the developments of the western economy, the western industrial organizational structure must be optimized. Aiming at the concrete situations of West China, we think the following measures should be taken.

\subsection{Constituting and implementing industrial organizational policies being fit for situations of West China}

The industrial organizational policies are the sum of a series of policies which are constituted by the government for solving conflicts among enterprises in the industry, actualizing the benefits of scale economy, developing effective competition, and pursuing the best resource scheme in the industry. The country constitutes and implements industrial organizational policies, actively intervenes in the industrial market structure and market behaviors, which has very important meaning for forming reasonable industrial organizational structure and obtaining perfect market effects. Generally, the industrial organizational policies are divided into two varieties. One is the anti-monopolized policies, and the other is the restrained excessive competition policies. The former usually is adopted in the backgrounds of high economical development level and large enterprise scales, and the later usually is adopted and implemented in the backgrounds of low economical development level and small enterprise scales. Comparing with the actuality of western industrial organizational structure, the main problem is the coexistence of small scale economy and administrated monopolization with low level excessive competition. So, correspondingly the West China should adopt industrial organizational policies with restrained excessive competition and developmental scale economy. That is to say, the market structure with competitive main bodies of few large-sized enterprises should be formed in the enterprises with remarkable benefits of scale economy. In the industry which products are composed by mass components, the reasonable labor division and collaboration among large-sized, middle-sized and small-sized enterprises and market structure with proper scales should be formed, which basic characters are that few large-sized enterprises and middle-sized and small-sized enterprises with quite quantity exist in the market, and the relation of specialized labor division and collaboration exists in the large-sized enterprises and middle-sized and small-sized enterprises, and large-sized enterprises implement high level competitions surrounding the market, and the middle-sized and small-sized enterprises implement low level competitions surrounding large-sized enterprises, and few large-sized enterprises which provide final products possess higher market concentration degree. In the industry without remarkable benefits of scale economy, we should encourage developing large-sized enterprises, and form the coexistence of large-sized, middle-sized and small-sized enterprises and the competitive market structure with more enterprises, which basic characters are that the whole market is divided by numerous enterprises, single enterprise occupies small market share, and the industrial concentration degree and the bulwark of in and out are low.

\subsection{Expediting governmental functional transformation and institutional reform}

Governmental functional transformation is the important guarantee for the favoring implementation of industrial organizational policies. First, the industrial organizational policies fully embody the active intervening of the government to the evolution of industrial organizational structure, but this intervening must mainly adopt indirect economical measures and legal methods, which naturally needs the economical management functions of the government make corresponding transformations, or else, the active influences of this intervening to the 
optimization of the industrial organizational structure will be seriously limited. Second, the first aim of the industrial organizational policies is to actualize scale economy, and the reasonable transformations of governmental functions can relieve various administrational limitations such as the limitation to the scale extension of the enterprises, the limitation to the self choice of specialized collaborate objects, and the limitation to the multiple managements of the enterprises, accordingly favor the full exertion of the scale benefits and the further extension of enterprise scales. The keys to implement the separation of the government and the enterprises and the transformation of governmental functions are to separate administrational functions of the government and the function of state-owned assets owner, and fully define the right boundary of the administrational institutions and owner functional institutions, accordingly establish a sort of new government and enterprise relation only with assets associations but without administrational subject relation. At the same time, to establish a developing oriented government with rationality, democracy, authority and high efficiency, we must fully reform the original institutions, which is the organizational guarantee to transform governmental functions and enhance efficiency. According to the requests of the operation of market economy, the original enterprise administrational departments should be respectively reconstructed to chastening comprehensive management department, state-owned assets operation institution and administrational management institution, and the crossed functions should be simplified and clarified. The personnel management system of the governmental institutions should be reformed, the personnel should be reasonable distributed, the civilian groups should be simplified and the diathesis of the civilian should be enhanced.

\subsection{Actively developing enterprise group and enhancing market concentration degree}

To develop enterprise group and enhance market concentration degree is the only way to actualize the economical increase in West China. Enterprise with different scales have different choices for enterprise profits (see Table 3), and which will influence the increase quality of the whole economy.

Enterprises with large scale always choose technical innovation and consumption reduction to make profits, but small-sized enterprises excessively consider how to increase market share. In R. Coase's book of "The Character of Enterprises", he put forward that to establish and actualize longitudinal integration of the enterprise can bring saving of trade costs. Coase thought that the market trade needed costs such as searching costs, bargaining costs and supervision costs, and the extension of enterprise scales could effectively reduce the market trade costs, accordingly enhanced the allocation efficiency of social resources. Therefore, at present, the West China should actively establish some large-sized enterprise groups according to the modern enterprise system through assets remnant reorganizations, take "optimized grouping, advantages complement, advantages expansion" as the orientation, fully develop enterprise groups, enhance industrial concentration degree, promote the technical innovation and consumption reduction, and develop industrial economy to the intensive directions with high quality.

\section{References}

Department of Industry \& Traffics of National Bureau of Statistics of China. (2004). China Industrial Economic Statistical Yearbook in 2004. Beijing: China Statistics Press.

Keying. (2002). From Excessive Competition to Oligarchs Monopolization: Choices of Domestic Industrial Organizational Optimization. Reformation \& Strategy. No.9.

Wang, Xiaoyan. (2002). On the Objective Pattern and the Practical Operation of China's Industrial Organization Optimization. Economic Survey. No.5.

Xiedi. (2000). Rationalization of Industrial Organization and Jilin Provincial Mode Transformation of Economical Increase. Social Science Front Bimonthly. No.5.

Table 1. Market concentration of 8 industries in West China in 2003

\begin{tabular}{|c|c|}
\hline Industry & Market Concentration $\left(\mathrm{CR}_{4}\right)$ \\
\hline Coal Mining and Dressing & 0.542 \\
\hline Petroleum and Natural Gas Extraction & 0.145 \\
\hline Beverage Production & 0.335 \\
\hline Production and Supply of Electric power and heat & 0.394 \\
\hline Smelting and Pressing of Nonferrous Metals & 0.503 \\
\hline Transport Equipment Manufacturing & 0.166 \\
\hline Petroleum Processing and Coking & 0.628 \\
\hline Tobacco Processing & 0.417 \\
\hline
\end{tabular}

Source: Department of Industry \& Traffics of National Bureau of Statistics of China. China Industrial Economic 
Statistical Yearbook in 2004. Beijing: China Statistics Press. Where, the total industrial production value adopts the invariable price of 1990, the industrial increase value and the total assets amount adopts the price of the same year.

Table 2. Proportional comparison of state-owned and state-owned holding industrial enterprises in the whole country, East China and West China in 2003 (Unit: \%)

\begin{tabular}{|c|c|c|c|}
\hline Index & Whole Country & East & West \\
\hline Proportion of enterprise unit amount & 17.47 & 11.10 & 35.89 \\
\hline Proportion of total industrial production value & 33.05 & 25.46 & 57.59 \\
\hline Proportion of industrial increase value & 44.86 & 34.43 & 71.88 \\
\hline Proportion of total assets amount & 55.99 & 44.23 & 72.88 \\
\hline
\end{tabular}

Source: Department of Industry \& Traffics of National Bureau of Statistics of China. China Industrial Economic Statistical Yearbook in 2004. Beijing: China Statistics Press. Where, the total industrial production value adopts the invariable price of 1990, the industrial increase value and the total assets amount adopts the price of the same year.

Table 3. Enterprise scales and choices of profitable method

\begin{tabular}{|c|c|c|c|c|c|}
\hline \multirow{2}{*}{ Scales Grouping } & \multicolumn{5}{|c|}{ Proportion of profitable method choice (\%) } \\
\cline { 2 - 6 } & $\begin{array}{c}\text { Technical } \\
\text { innovation }\end{array}$ & $\begin{array}{c}\text { Reducing } \\
\text { consumption }\end{array}$ & $\begin{array}{c}\text { Increase market } \\
\text { share }\end{array}$ & $\begin{array}{c}\text { Advertisement } \\
\text { drumbeating }\end{array}$ & $\begin{array}{c}\text { Enhancing } \\
\text { prices }\end{array}$ \\
\hline $\begin{array}{c}\text { State-owned } \\
\text { oversized } \\
\text { enterprise }\end{array}$ & 41.2 & 47.1 & 5.9 & 0.0 & 5.9 \\
\hline $\begin{array}{c}\text { State-owned } \\
\text { large-sized } \\
\text { enterprise }\end{array}$ & 46.1 & 29.7 & 21.1 & 0.8 & 2.3 \\
\hline $\begin{array}{c}\text { State-owned } \\
\text { small-sized } \\
\text { enterprise }\end{array}$ & 44.2 & 26.9 & 23.1 & 0.0 & 5.8 \\
\hline
\end{tabular}

Source: Ma, Jiantang. (1993). Structure and Behavior. 